\title{
A new species of Tenuiphantes Saaristo et Tanasevitch, 1996 (Aranei: Linyphiidae) from Adygea, the Caucasus, Russia
}

\author{
Новый виА Tenuiphantes Saaristo et Tanasevitch, 1996 \\ (Aranei: Linyphiidae) из Адыгеи, Кавказ, Россия
}

\author{
A.V. Tanasevitch ${ }^{1}$, A.V. Ponomarev ${ }^{2}$, Yu.A. Chumachenko ${ }^{3}$ \\ А.В. Танасевич ${ }^{1}$ А.В. Пономарёв ${ }^{2}$, Ю.А. Чумаченко ${ }^{3}$

\footnotetext{
${ }^{1}$ Institute of Ecology and Evolution, Russian Academy of Sciences, Leninsky prospekt, 33, Moscow 119071, Russia. E-mail: tanasevitch@gmail.com

Институт проблем экологии и эволюции РАН, Ленинский проспект, 33, Москва 119071, Россия.

${ }^{2}$ Institute of Arid Zones, Southern Scientific Centre, Russian Academy of Sciences, Chekhov str., 41, Rostov-on-Don 344006, Russia. Email: ponomarev1952@mail.ru

Институт аридных зон, Южный научный центр РАН, пр. Чехова, 41, Ростов-на-Дону 344006, Россия.

${ }^{3}$ Caucasian State Biosphere Nature Reserve, Sovetskaya str., 187, Maykop 385000 Russia. E-mail: ychumachenko73@mail.ru

Кавказский государственный природный биосферный заповедник, ул. Советская, 187, Майкоп 385000, Россия.
}

KEY WORDS: Spiders, Micronetinae, Adygea, Lagonaki Plateau, the northern Caucasus, Russia, subalpine, new species.

КЛЮЧЕВЫЕ СЛОВА: Пауки, Micronetinae, Адыгея, плато Лагонаки, Северный Кавказ, Россия, субальпика, новый вид.

ABSTRACT. Tenuiphantes lagonaki sp.n. $\left(\sigma^{7}\right)$ is described from the mountains of the northern Caucasus, Adygea. The new species is most similar to the Anatolian T. wunderlichi Saaristo et Tanasevitch, 1996, from which it readily differs in the shape of the lamella characteristica and the toothless embolic base.

РЕЗЮМЕ. С гор Северного Кавказа (Адыгея) описан Tenuiphantes lagonaki sp.n. $\left(\mathrm{O}^{7}\right)$. Новый вид близок к анатолийскому T. wunderlichi Saaristo et Tanasevitch, 1996, от которого хорошо отличается формой lamella characteristica, а также отсутствием зубцов на основании эмболюса.

\section{Introduction}

While studying the spider fauna of Lagonaki Plateau in Adygea (the northern Caucasus), a new species of Tenuiphantes Saaristo et Tanasevitch, 1996 has been found. Description of the new species is the goal of this paper.

All spider specimens were collected by pitfall traps, preserved in $70 \%$ ethanol and studied be means of a MBS-9 stereo microscope. The type material is deposed in the collection of the Zoological Museum of the Moscow University, Russia (ZMMU; curator K.G. Mikhailov).

In the description, the sequence of leg segments in measurement data is as follows: femur + patella + tibia + metatarsus + tarsus. All measurements are given in $\mathrm{mm}$. Scale line in the figures corresponds to $0.1 \mathrm{~mm}$.
The terminology of genitalic structures follows that of Saaristo \& Tanasevitch [1996].

The following abbreviations are used in the text and figures: BE — base of the embolus; EP — embolus proper; $\mathrm{MM}$ - median membrane; $\mathrm{Mt}$ - metatarsus; $\mathrm{PH}$ - pit hook; SS — serrate surface.

\section{Description}

\section{Tenuiphantes lagonaki sp.n.}

Figs 1-8.

TYPES. Holotype $\sigma^{7}$ (ZMMU) from Russia, the northern Caucasus, Adygea Republic, Maikop Distr., SE slope of Plateau Lagona$\mathrm{ki}$, upper reaches of Armyanka River, "Instruktorskaya Shchel" Valley $\left(44.014317^{\circ} \mathrm{N}, 39.981650^{\circ} \mathrm{E}\right), 1853 \mathrm{~m}$ a.s.l., subalpine meadow, pitfall traps, 8-23.VIII.2013, leg. Yu. Chumachenko. PARATYPES: $1 \sigma^{7}$ (ZMMU), the same locality, pitfall traps, 23.VIII.-11.IX.2013, leg. Yu. Chumachenko; $1 \mathrm{O}^{\text {T }}$ (ZMMU), Plateau Lagonaki, nr. Azishskiy Pass $\left(44.075861^{\circ} \mathrm{N}, 40.013417^{\circ} \mathrm{E}\right), 1810 \mathrm{~m}$ a.s.l., forest with Abies nordmanniana \& Betula litwinowi, diverse herbs in clearing, pitfall traps, 16-19.VII.2015, leg. A.V. Ponomarev.

ETYMOLOGY. The species name is a noun in apposition taken from the terra typica, the Plateau Lagonaki.

DIAGNOSIS. The new species is most similar to the Anatolian Tenuiphantes wunderlichi Saaristo et Tanasevitch, 1996, but can readily be distinguished by the presence of three well sclerotized branches of the lamella characteristica (two in T. wunderlichi) and the arched distal part of the embolus, the absence of a tooth in the distal part of the paracymbium, as well as by the toothless embolic base. 

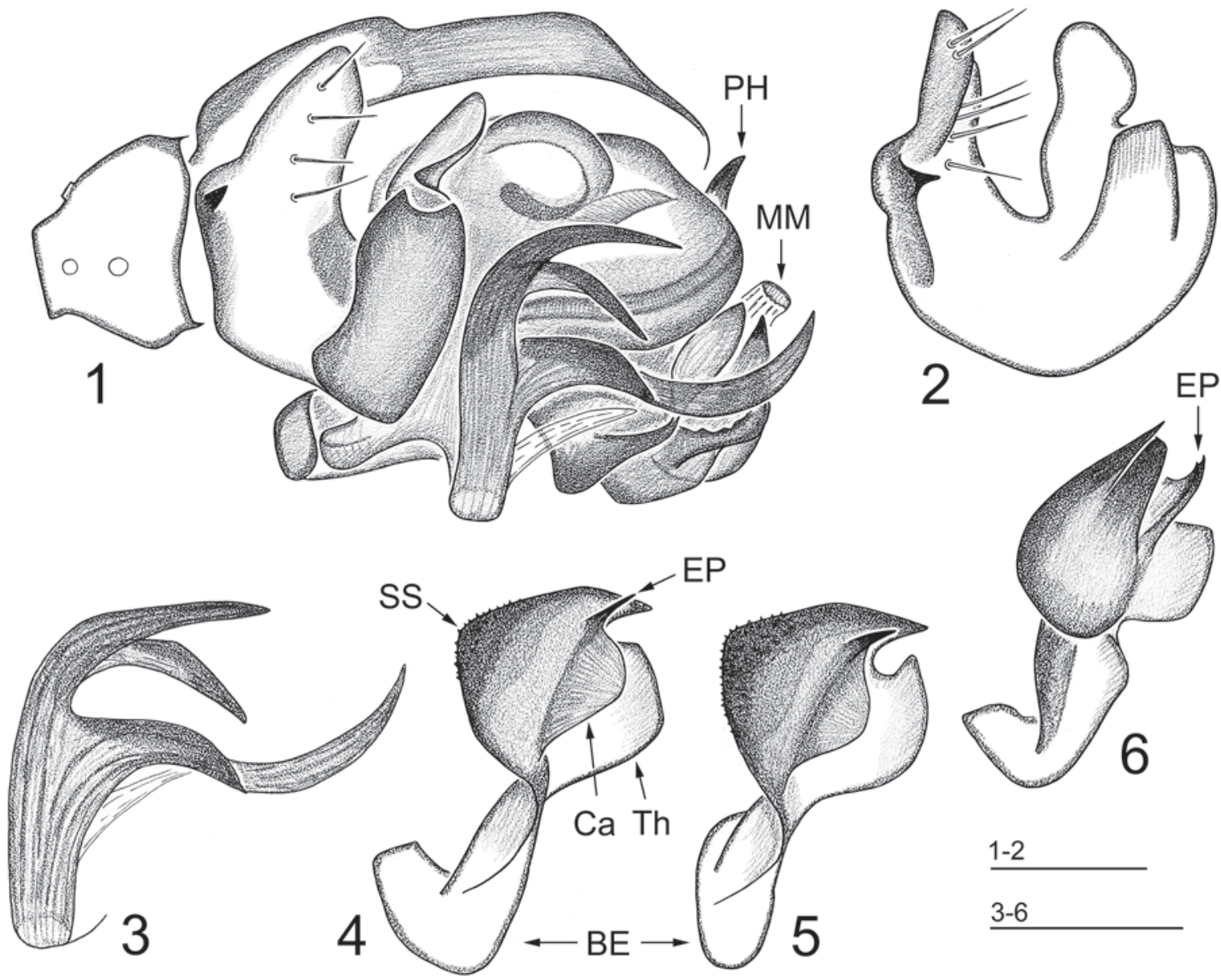

Figs 1-6. Tenuiphantes lagonaki sp.n., holotype (1-2) and paratype from "Instruktorskaya Shchel” Valley (3-6): 1 - right palp; 2 - paracymbium; 3 - lamella characteristica; 4-6 - embolus, different aspects.

Рис. 1-6. Tenuiphantes lagonaki sp.n., голотип (1-2) и паратип из ущелья «Инструкторская щель» (3-6): 1 - правая пальпа; 2 — парацимбиум; 3 - lamella characteristica; 4-6 - эмболюс, различные аспекты.

DESCRIPTION. MALE (the holotype). Total length 2.13. Carapace unmodified, 1.03 long, 0.85 wide, pale brown, with darker margins. Chelicerae 0.40 long. Almost all legs are lost; remaining segments brownish yellow. FeI, 1.18 long, FeIV, 1.20 long. Palp (Figs 18): Palpal tibia without a special spine. Paracymbium relatively large, with a small, sharp tooth in it proximal part. Lamella characteristica with three well sclerotized branches, of which the lowest one is smoothly curved and twice as long as others. The distal part of embolus arched, serrate surface present. Carina and thumb well developed. Basal part of embolus toothless. Abdomen 1.25 long, 0.80 wide, dorsally with a dark, "T"-shaped spot turned upside down in the anterior part, and transverse narrow bands posteriorly.

FEMALE unknown.
DISTRIBUTION. Known only from Plateau Lagonaki, Adygea, the Caucasus.

ACKNOWLEDGEMENTS. We are very grateful to Dmitri V. Logunov (Manchester, UK) for editing the English of the final draft.

\section{Reference}

Saaristo M.I., Tanasevitch A.V. 1996. Redelimitation of the subfamily Micronetinae Hull, 1920 and the genus Lepthyphantes Menge, 1866 with descriptions of some new genera (Aranei, Linyphiidae) // Ber. nat.-med. Verein Innsbruck. Bd.83. P.163-186. 